\title{
Impact of magnetic fuel activators on the combustion process in metallurgical heating furnaces
}

ABSTRACT: The article presents the results of tests of the application of magnetic fuel activators, which improve the efficiency of metallurgical furnaces and positively affect the ecological aspects of their work. Energy indicators for metallurgical furnaces during operation before and after installation of magnetic fuel activators as well as the results of composition and concentration of emitted pollutants are included in the paper.

The magnetic activation of liquid and gaseous fuels modifies their structure. As a result of the activation, the fuel mixture is selectively saturated with oxygen in the zone of free fuel flow. The combustion conditions were close to optimal, which is confirmed by the reduction of pollutants in the exhaust gases. Fuel saving in the combustion process is also a measurable economic effect. The tests included ovens of several types: pusher furnace, one and two chamber furnaces and a furnace with a rotary shaft. Several-month measurement cycles were carried out on each of them. The experiments consisted in the analysis of gas and heat consumption per month in individual furnaces before and after the use of magnetic fuel activators. The effectiveness of using activators was determined on the basis of the results of the tests carried out. As a result of a twelve-month test cycle on the pusher type furnace, a $36 \%$ reduction in gas consumption and a $22 \%$ reduction in heat consumption were achieved. After a seventeen-month measurement cycle on chamber furnaces, a 35\% reduction in gas consumption and $6 \%$ in heat consumption were achieved. The tests on furnaces

\footnotetext{
${ }^{1}$ Faculty of Infrastructure and Environment, Politechnika Częstochowska, Częstochowa, ORCID: 0000-00015065-9311; e-mail: pszymanek@is.pcz.czest.pl

2 Strata Mechanics Research Institute, Polish Academy of Sciences, Kraków; ORCID: 0000-0003-4390-4256; e-mail: pajdak@img-pan.krakow.pl

3 Faculty of Mechanical Engineering and Computer Sciences, Politechnika Częstochowska, Częstochowa, ORCID: 0000-0002-4235-2368; e-mail: szymanek@imc.pcz.czest.pl
} 
with a rotary shaft lasted fourteen months and showed a reduction in gas consumption by $8 \%$. An improvement in the composition of fumes in the furnace atmosphere was achieved in all units with magnetic activators installed, as well as a reduction in the emission of harmful pollutants into the atmosphere from the installation.

KEYWORDS: magnetic activation, magnetic mill, metallurgical furnaces, fuel, combustion

\section{Introduction}

The history of research into the influence of external magnetic field on flowing fluids dates back to the 1930s. The first patent concerning the improvement of water quality by the magnetic field of a magnet was filed in 1890 in Germany. World War II saw the intensive development of magnetic activators of liquid fuels, which resulted in the creation of a magnetic device enhancing the combustion process in aircraft piston engines in 1942. That invention made it possible to simultaneously limit the emission of unburned hydrocarbons and soot particles from fighter and member planes as well as to reduce fuel consumption, which increased the range of the planes. The next stage of the development of the idea of magnetic field applications concerned ballistic missiles, rockets and later in space shuttles at NASA (Patent US 3228868A 1958). Subsequently, magnetic activators were used for other fuels such as: natural gas, petrol, diesel oil, fuel oil as well as in the automotive industry and home installations (Kulakov et al. 2017, 2018).

Magnetic activators differ in the geometry of the magnetic system and the ways they are installed in the fuel lines (they are installed inside the walls of the fuel lines or on their external surfaces). They also vary in efficiency (Fedorchak and Fedorchak 2015). The evolution of solutions aiming to improve the working parameters and efficiency lead to the development of new generation devices (Patent PL 214633 2013; Patent PL 186233 2003; Patent US 143045 2000; Szczypiorowski 1994). Their prototypes were tested in Poland in the years 1995-2007 in industrial furnaces heated with coke oven gas, blast furnace gas, natural gas, mazut and air-dust mixtures from coal (Szczypiorowski 1993, 1994; Szczypiorowski and Nowak 1995; Michalak 1994; Witaszak 1995).

The process of effective hydrocarbon conversion in fuel can be rather complex. Hydrocarbons have a frame-like molecular structure hence the oxidization of carbon atoms located inside their matrix is hindered. They also combine in pseudo-compounds which create associated molecules. The inflow of the proper amount of oxygen into those associated molecules is limited. Due to the oxygen deficiency, the combustion of associated molecules is incomplete. Numerous studies aiming to counteract the effect of fuel association and to improve the efficiency of their combustion do not provide satisfactory results. In spite of implementation of various methods, the problem of the relatively high content of $\mathrm{CO}$ and $\mathrm{HC}$ in fumes still persists. 
The processes of magnetic activation are applied in many technologies in the field of energetics. In (Sławiński et al. 2014a) a magnetic mill was used to dry and crush coal and in (Sławiński et al. 2014b) the process of magnetic activation was used to enrich alternative fuels based on mixtures of industrial refuse. The authors of (Walawska et al. 2016) and (Pajdak and Walawska 2016) presented a methodology of the electromagnetic milling of carbonate compounds improving their capacity to sorb impurities in exhaust gases. Magnetic activation during the combustion of liquid fuels and gas fuels is applied based on the Van der Wals theory (Mozga and Stoeck 2018). It follows from the research (Patent PL 214633 2013) that a properly optimized external magnetic field is able to modify the molecular structure of fuels and to converse the hydrogen contained in them from para form into ortho form (characterized by increased volatility and reactivity), which makes it possible to intensify the combustion processes. Magnetically modified and mixed with air, fuel becomes more oxygenated and burns almost completely, which results in the reduction of toxic elements of fuels and fuel consumption. A number of phenomena occur in the zone in which fuel flows through a magnetic field i.e., turbulences of the trajectory of the particles, circulating eddy currents, electric and internal magnetic fields as well as changes in velocity and pressure. The molecules of the fuel are subjected to the twisting effect in properly adjusted magnetic fields. This can visually be observed based on the refraction of light rays passing through the column of the liquid fuel. The magnetic rotation of molecules is a function, among others, of magnetic field intensity, density and velocity of the fuel and magnetic moments. Additional magnetic moments also appear, which order elections at the atomic and molecular level. The structure of hydrocarbon relaxes and the molecules become ordered and polarized. This results in changes in the fuel structure and the saturation of the fuel mixture with oxygen. As a result it is more active and the combustion process is faster and more complete. The combustion conditions of such a mixture are close to optimal, which leads to a significant reduction of toxic substances $\left(\mathrm{CO}, \mathrm{HC}, \mathrm{NO}_{\mathrm{x}}\right)$ in fumes.

\section{Magnetic fuel activator}

An example scheme of a basic component of a new generation magnetic fuel activator according to an original patent (Patent PL 186233 2003) is presented in Figure 1. It consists of magnetic blocks in the form of stacks, mounted symmetrically and longitudinally around the fuel line. The blocks are built of plate anisotropic ceramic magnets of energy of (BH) $\max 33 \mathrm{~kJ} / \mathrm{m}^{3}$, and remanence of $(\mathrm{Br}) 400 \mathrm{mT}$. They have S-polarisation relative to the wall of the fuel line and they are connected by keepers in the form of trapezoidal segments. Depending on the diameter of the fuel line the elementary units are grouped into multipart segments sets. 


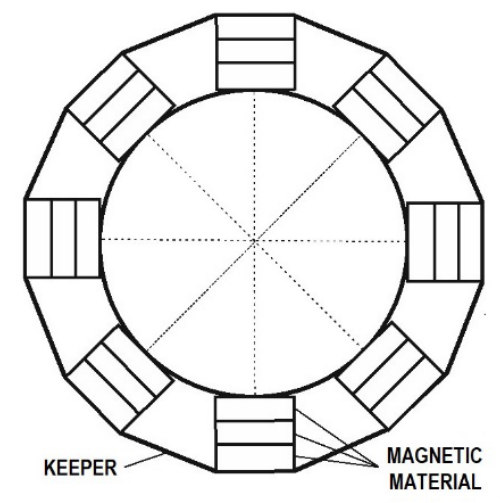

Fig. 1. Scheme of the basic component of the magnetic fuel activator (Patent PL 214633 2013)

Rys. 1. Schemat podstawowej jednostki składowej magnetycznego aktywatora paliw

\section{Description of the research objects}

This research included experiments on five furnaces of various type for heating steel up to the rolling temperature of $1,250-1,350^{\circ} \mathrm{C}$.

\subsection{Pusher furnace}

The pusher furnace, presented in Figure 2, is heated with natural gas and is designated for heating steel slabs with a cross-section of $0.12 \times 0.2$ and a length of $1.8-2 \mathrm{~m}$ (two-row) and $3.1-4 \mathrm{~m}$ (single-row) up to the rolling temperature of $1,150-1,250^{\circ} \mathrm{C}$. The furnace is equipped with $14,250 \mathrm{~kW}$ flat-flame vault burners, arranged in two rows and 16,400 kW burners (two-row version) as well as four $1,500 \mathrm{~kW}$ bottom burners. Four-element sets of the magnetic fuel activator were installed on the main gas collectors and the two-element versions on their branches to each burner.

\subsection{Pit furnaces with one chamber and two chambers}

Another two pit furnaces with two chambers, presented in Figure 3, are designated for heating steel slabs with a cross-section of $0.38 \times 0.35 \mathrm{~m}$ and $0.38 \times 0.54 \mathrm{~m}$, a length of $1.9-2.1$ 


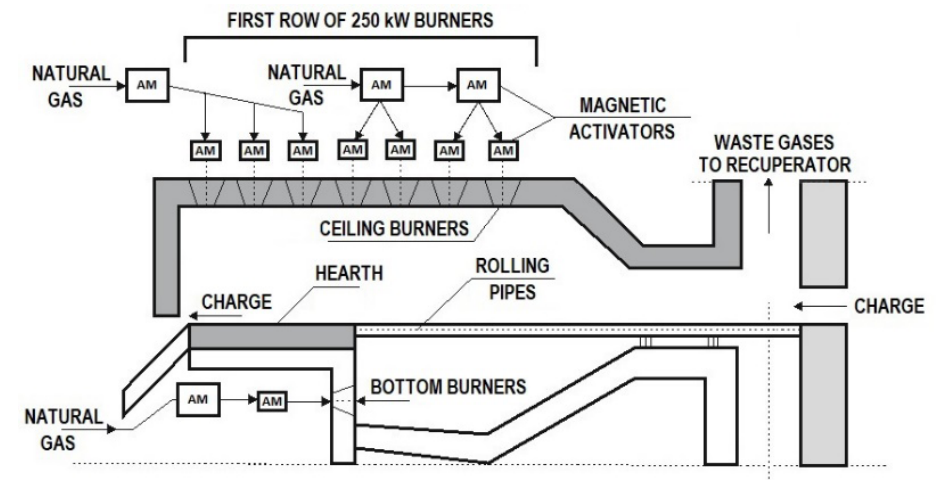

Fig. 2. Scheme of a pusher furnace with a gas installation and location of activators

Rys. 2. Schemat pieca przepychowego $(4,700 \times 15,000)$ z instalacją gazową i lokalizacją aktywatorów

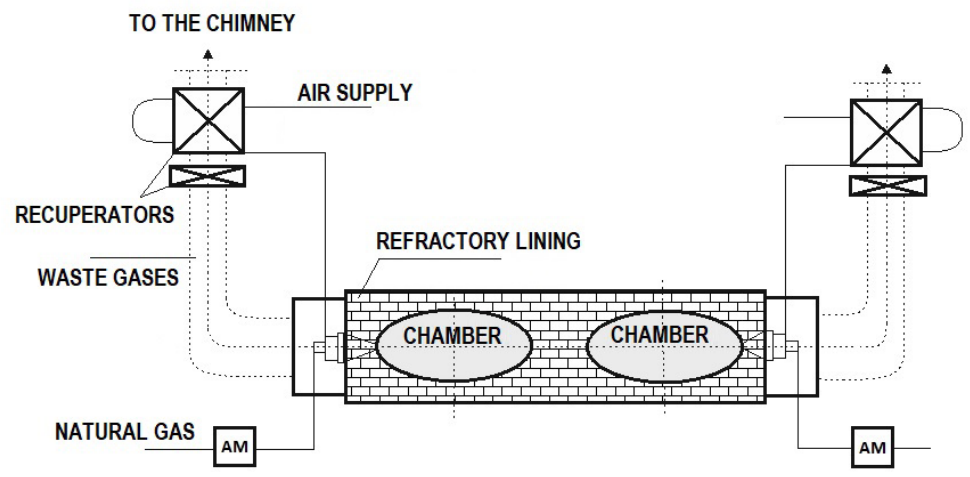

Fig. 3. Scheme of a two-chamber furnace with a gas installation and location of activators

Rys. 3. Schemat pieca dwukomorowego z instalacją gazową i lokalizacją aktywatorów

and a weight of 2-3.5 $\mathrm{t}$ up to the rolling temperature of $1,320^{\circ} \mathrm{C}$. Those furnaces are heated with natural gas and they discharge fumes to the common emitter. Each heating chamber is equipped with a $4,300 \mathrm{~kW}$ burner with a flame regulator. Four-element sets of the magnetic fuel activator were installed on the fuel lines of each heating chamber.

On the single-chamber pit furnace the charge and the fuel were the same as in the two-chamber furnaces. However, the location of the magnetic fuel activator was the same as in the case of the pusher furnace. 


\subsection{Rotary hearth furnace}

A metallurgical heating furnace with a rotary hearth is designed for the side loading and unloading of ingots and slabs with the square sides with a width of 245-400 mm and a length of $1,000-1,600 \mathrm{~mm}$. The rotary hearth in the shape of a ring transports the charge from the charging door through the chamber to the axis of the charging opening with the temperature of $1,320^{\circ} \mathrm{C}$. The furnace is heated with coke oven gas with an admixture of natural gas and blast furnace gas with a calorific value of $5,000 \mathrm{kcal} / \mathrm{m}^{3}$. The furnace is equipped with 42 flat-flame gas burners, installed in the ceilings of three heating zones with automatic regulation. The total heating power of in the zones is $11,160 \mathrm{~kW}$. For the time of the experiment, one the furnace was fitted with three -element magnetic activators, mounted on the three main gas collectors, distributing the fuel to the branches of the flat-flame vault burners.

\section{Methodology of calculations}

The research was based on the analyses of specific gas consumption in particular furnaces before and after the implementation of a magnetic fuel activator. The measurements were carried out in successive time periods, which lasted from several to between ten and twenty months. On the basis on the data from the furnaces i.e. monthly charge and monthly gas consumption, the researchers determined specific heat consumption and the specific heat consumption rate from the following formulas:

$$
\begin{gathered}
G=\frac{W_{u} \cdot E}{m} \\
U=\frac{W_{u} \cdot \Sigma E}{\Sigma m}
\end{gathered}
$$

The calorific value was different for each month and it fell in the range of 34,369-27,660 kJ/kg.

During the analyses on the research objects the average yield index was taken into account i.e. the charge minus the mass of the scale. The scale is formed in the exchange process of the heat and mass between the furnace atmosphere and the surface of the heated steel. Its oxidization results in steel losses, which can amount even over $5 \%$ of the charge mass in a single heating. Apart from the direct losses, the scale also causes a number of indirect losses such as the decreased durability of furnace devices and the refractory lining as well as well as surface defects caused by overlaps. Moreover, the small value of the heat conductivity coefficient of the scale layer has a negative effect on heating intensity, which results in considerable heat loss. 


\section{Results}

The material and energy balance before and after installing the magnetic activators in the pusher furnace is presented in Figure 4.

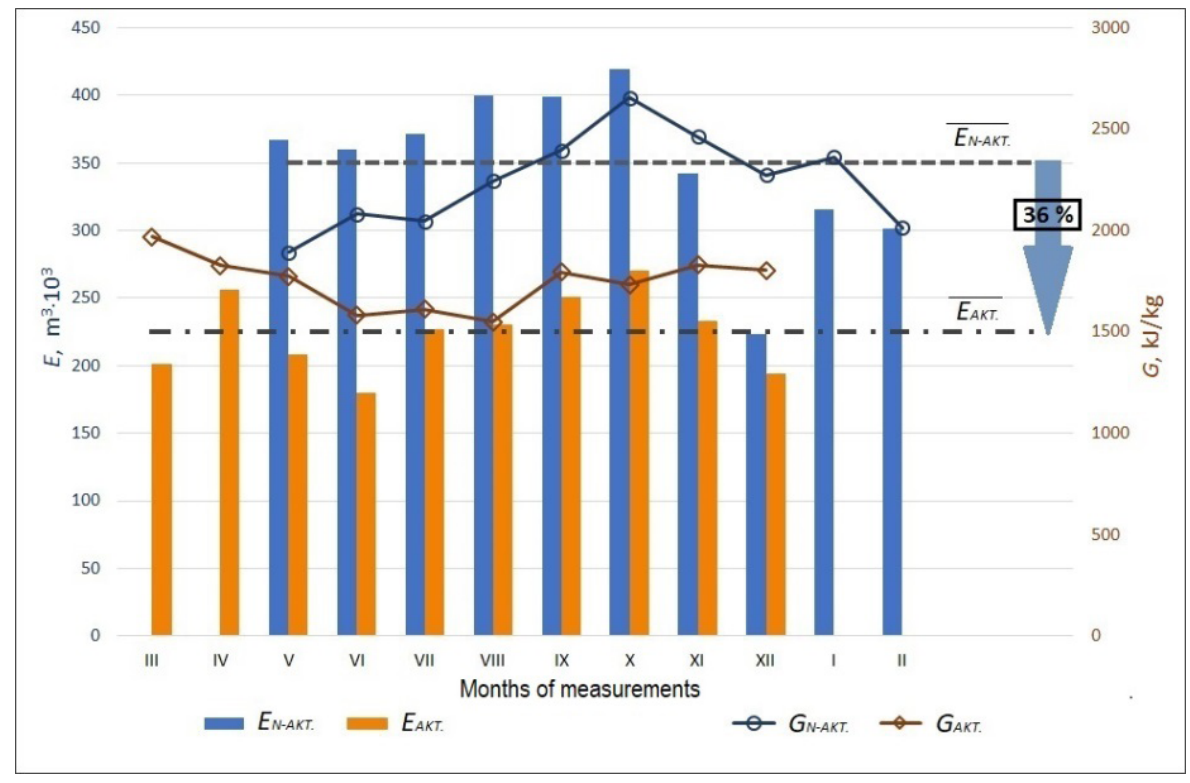

Fig. 4. Gas and heat consumption per month in a pusher furnace

Rys. 4. Jednostkowe zużycie gazu i ciepła w piecu przepychowym

According to the design assumptions the heat consumption for this furnace is $1,880 \mathrm{~kJ} / \mathrm{kg}$. The average gas consumption from the ten-month base time period preceding the installation of magnetic activators was $350 \cdot 10^{3} \mathrm{~m}^{3}$. After the implementation of the fuel activation method on that object, the average value of that index decreased to $225 \cdot 10^{3} \mathrm{~m}^{3}$. The average heat consumption also decreased from $2,243 \mathrm{~kJ} / \mathrm{kg}$ to $1,748 \mathrm{~kJ} / \mathrm{kg}$. As a result of the installation of the magnetic activators, the average heat consumption decreased by $22 \%$, which is $756,436 \mathrm{~m}^{3}$ per year.

An important and positive aspect of the implementation of magnetic activators in the pusher furnace was also the reduction of concentration of selected pollutants in flue gases and a $0.7 \%$ reduction of steel loss caused by scaling.

Subsequently, magnetic activators were installed in two identical pit furnaces with two chambers and one pit furnace with a single chamber. The material and energy balance for one of the two-chamber furnaces from before and after the installation of magnetic activators is presented in Figure 5. 


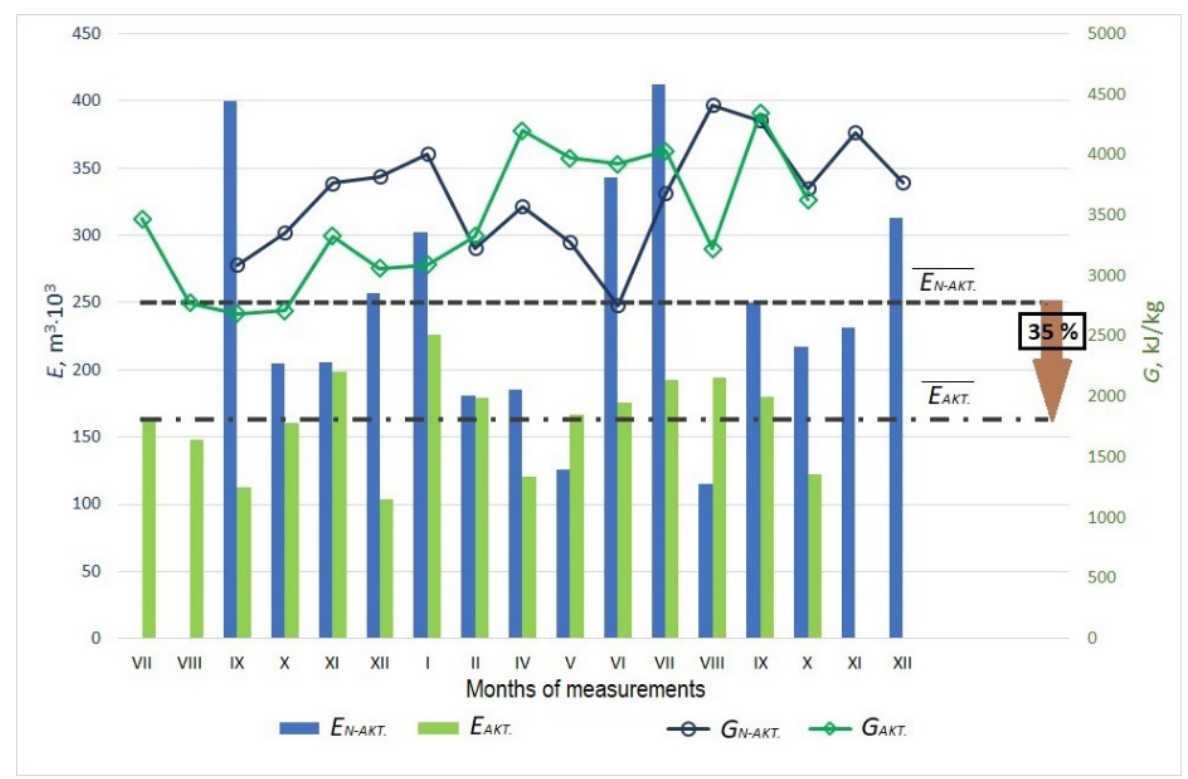

Fig. 5. Gas and heat consumption per month in a pit furnace

Rys. 5. Jednostkowe zużycie gazu i ciepła w piecu wgłębnym

Thanks to the magnetic activators, the average gas consumption decreased from $250 \cdot 10^{3}$ $\mathrm{m}^{3}$ to $163 \cdot 10^{3} \mathrm{~m}^{3}$. The mean value of specific heat consumption also decreased from $3,661 \mathrm{~kJ} /$ $\mathrm{kg}$ to $3,450 \mathrm{~kJ} / \mathrm{kg}$. The experiments on the single-chamber furnace showed a $35 \%$ decrease of heat consumption per ton of the charge. Also, specific gas consumption fell by $6 \%$, which is $666,365 \mathrm{~m}^{3}$ per year.

The average yield index from one ton of charge for the pit furnaces before the installation of magnetic activators was 0.7974 and $0.8647(8.4 \%)$ after it. The increase of yield per ton of charge for these furnaces after the implementation of the magnetic activators, for the amount of charge heated during the experiment session (70,498 tons) allowed the amount of material used to be decreased by 6,881 tons. In total, the decrease in the material used in the pusher furnace and the pit furnaces amounted to 7,220 tons, which is about 13,600 tons per year.

The concentration of selected pollutants contained in the gas also dropped. Table 1 shows average values of technical parameters and the elemental composition of gas from the emitters of the two identical pit furnaces before and after the installation of magnetic activators. Table 1 presents average values from 10 measurement series included in an annual measurement period of fume composition.

Other experiments included a fourteen-month period of operation of two identical furnaces with rotary hearths (Fig. 6) but the gas network of one of them was equipped with magnetic fuel activators. The analysis of basic data from an eight-month cycle of simultaneous operation of both furnaces revealed that identical masses of charge were heated in the chambers with comparable gas consumption. Steel of the same type was used as the charge. 
TABLE 1. Technical parameters and the concentration of selected pollutants in waste gases from before and after the implementation of magnetic fuel activators in the pit furnaces

TABELA 1. Parametry techniczne i stężenie wybranych zanieczyszczeń w gazach odlotowych z okresu przed i po wdrożeniu magnetycznych aktywatorów paliwa w piecach wgłębnych

\begin{tabular}{|l|l|c|c|c|c|c|c|}
\hline \multicolumn{2}{|c|}{ Parameters and waste gases composition } & $\mathrm{T}$ & $\begin{array}{c}\text { Flow } \\
\text { intensity }\end{array}$ & $\rho_{\mathrm{CO}}$ & $\rho_{\mathrm{NO}}$ & $\rho_{\mathrm{O}_{2}}$ & $\rho_{\mathrm{CO}_{2}}$ \\
\hline \multicolumn{2}{|c|}{ Unit } & $\mathrm{K}$ & $\mathrm{m}^{3} / \mathrm{h}$ & $\mathrm{mg} / \mathrm{m}^{3}$ & $\mathrm{mg} / \mathrm{m}^{3}$ & $\%$ & $\%$ \\
\hline \multirow{2}{*}{$\begin{array}{l}\text { Average values of waste } \\
\text { gases composition }\end{array}$} & $\begin{array}{l}\text { Furnace without } \\
\text { a magnetic activator }\end{array}$ & 549 & 28,225 & 57 & 79.90 & 18.80 & 1.05 \\
\cline { 2 - 8 } & $\begin{array}{l}\text { Furnace with } \\
\text { a magnetic activator }\end{array}$ & 533 & 32,320 & 15 & 48.00 & 17.80 & 1.20 \\
\hline $\begin{array}{l}\text { Percentage change of the values of the parameters } \\
\text { and the components of waste gases \% }\end{array}$ & -2.91 & 14.51 & -73.68 & -39.92 & -5.32 & 14.29 \\
\hline
\end{tabular}

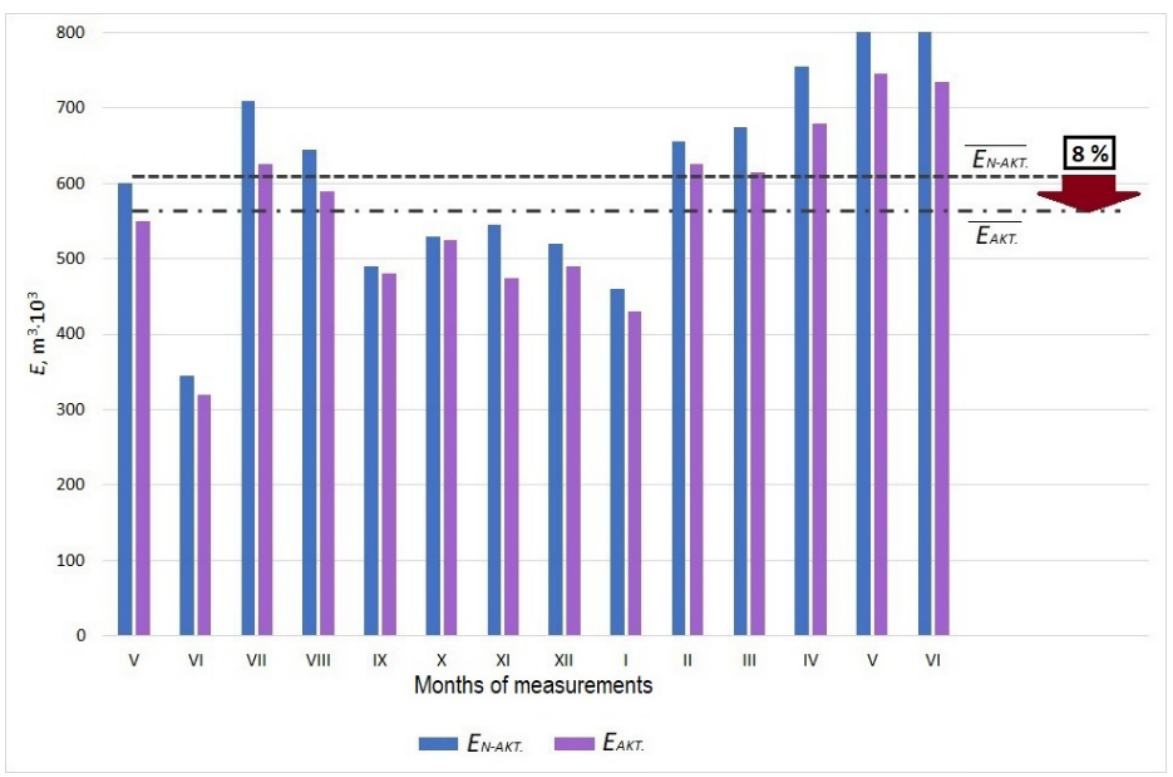

Fig. 6. Gas consumption per month in a furnace with a rotary shaft

Rys. 6. Jednostkowe zużycie gazu w piecu z trzonem obrotowym

The comparative analysis of simultaneous operation of both furnaces with rotary hearths showed that the furnace with magnetic activators obtained a drop of average specific gas consumption from $609 \cdot 10^{3} \mathrm{~m}^{3}$ to $563 \cdot 10^{3} \mathrm{~m}^{3}$, which is $8 \%$ less. The annual decrease of coke oven gas consumption of this furnace amounted to $112,620 \mathrm{~m}^{3} /$ year.

The analysis of average measurement results of the parameters of waste gases from those furnaces from an eight-month operation period before the implementation of magnetic activators in one of them showed that the composition of waste gases from those furnaces was comparable. 
After the magnetic activators were installed in one of the furnaces the waste gases temperature, the concentration of $\mathrm{O}_{2}$ and $\mathrm{CO}$ dropped by $12.5 \%, 25 \%$ and $49 \%$ respectively. The content of $\mathrm{CO}_{2}$ increased by $105 \%$.

A randomly performed, monthly material balance for those two furnaces revealed that the masses of the loaded material were 4,753.1 and 4,753.3 t, with a $0.2 \mathrm{t}$ difference. However, in the furnace with magnetic activators the mass of the unloaded material increased by $60 \mathrm{t}$. The difference is caused by scale i.e. $1.28 \%$ of oxidized steel. It can be stated that the improvement of waste gases composition including a decrease of $\mathrm{O}_{2}$ content and an increase of $\mathrm{CO}_{2}$ in the atmosphere of a furnace has a positive effect as it reduces the mass of scale. Heating charge is very important in plastic processing and thermal treatment processes. The costs of heating exceed any other costs connected with plastic processing.

The tests of magnetic activators carried out on the aforementioned objects proved that their implementation not only improved the composition of waste gases but also resulted in a significant reduction of fuel consumption, which, in total, amounted to annual savings of $2,246 \cdot 10^{3} \mathrm{~m}^{3 /}$ year of gas. Moreover, the steel losses due to scaling also decreased, which is positive from the economical point of view. These findings are confirmed by the data concerning the yield from the time period before the implementation of magnetic activators and after it. Figure 7 shows changes in the specific gas consumption for particular furnaces.

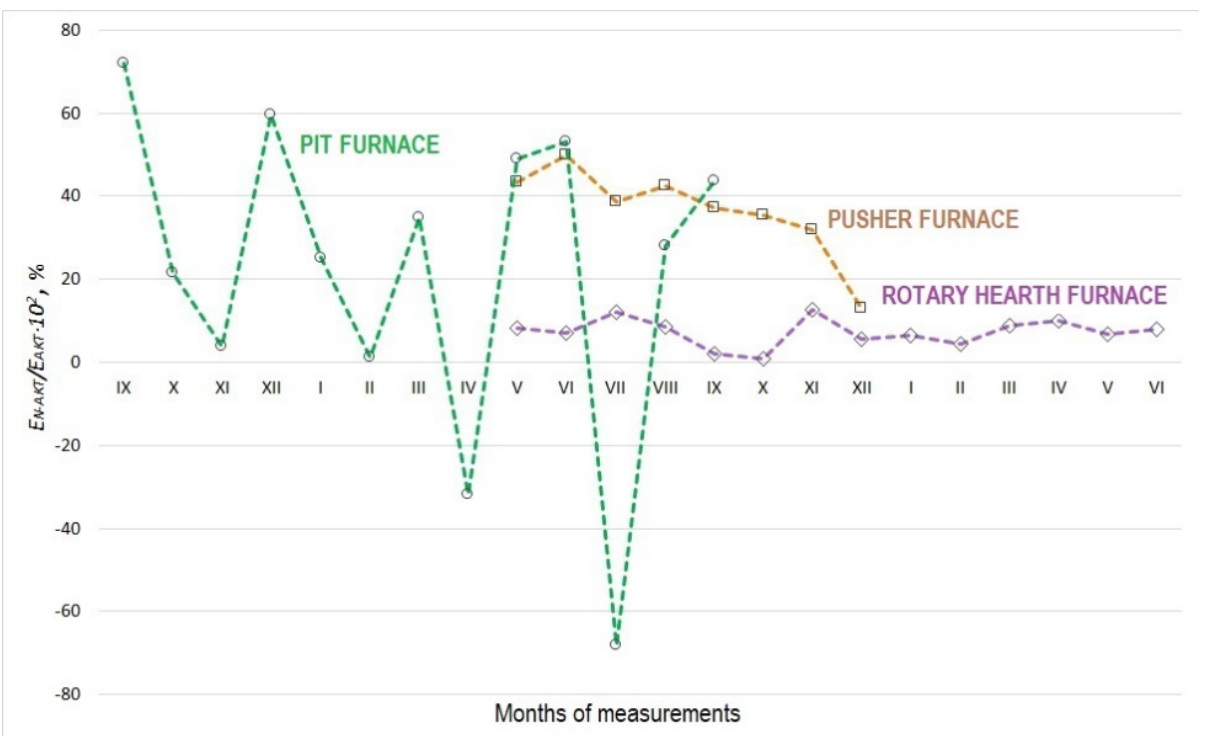

Fig. 7. A juxtaposition of the changes in fuel consumption per month in the examined furnaces

Rys. 7. Zestawienie zmian jednostkowego zużycia paliwa w badanych obiektach energetycznych

The results of cinomatographic analysis showed that the combustion of magnetic activated fuel modifies the structure of the flame in the zone close to the burner i.e. shortens it and at the 
same time widens it at the outlet of a burner. Those changes result in an emission increase and a homogenization of the temperature field by limiting the thermal peaks. The limitation of the number of thermal peaks is beneficial because of the reduction of $\mathrm{NO}_{\mathrm{x}}$ emission.

\section{Summary}

The results of the industrial research concerning the magnetic activation of typical gas fuels of metallurgical furnaces prove that after the implementation of a full set of magnetic activators, a real reduction of fuel consumption is possible. During experiments on the pusher furnace, the researchers achieved a drop in the average fuel consumption for twelve-month measurement cycles at the level of $36 \%$. In the pit furnaces, the difference in the average seventeen-month gas consumption amounted to $35 \%$ and in the furnaces with rotary hearths, after a fourteen-month measurement cycle, it was $8 \%$.

The combustion of magnetically activated fuel improves the composition of the waste gases in the furnace atmosphere, intensifies heating of the charge before plastic processing and makes it possible to obtain the required temperature using a smaller number of energetic media which results in a decrease of the scale mass.

On the basis of the conducted research, the researchers observed a decrease in the specific heat consumption and the change in the composition of the waste gases, which reduces the emission of toxic substances into the atmosphere. The implementation of magnetic fuel activators made it possible to decrease the average heat consumption by $22 \%$ in the pusher furnace and $6 \%$ in pit furnaces. From the ecological point of view, the effect of the action of a magnetic fuel activator is comparable to the action of a catalytic converter.

New generation magnetic activators are characterized by high durability and efficiency, compactness, small weight, ease of installation and the ability to optimize the combustion process.

They are a simple and economically justified solution in terms of lower fuel consumption and ecology. Hence they are implemented in objects of other types. Their implementation in metallurgy can produce positive results. Apart from notable economic effects, this solution will allow to make the large scale and energy consuming metallurgical technologies more ecological.

The presented research results are a strong reason for the implementation of this method in other types of furnaces. Obtaining optimal effects requires a detailed project and individual selection of activators for particular objects.

The authors would like to thank Joanna Szymańska for her help in preparing the material for this paper. 


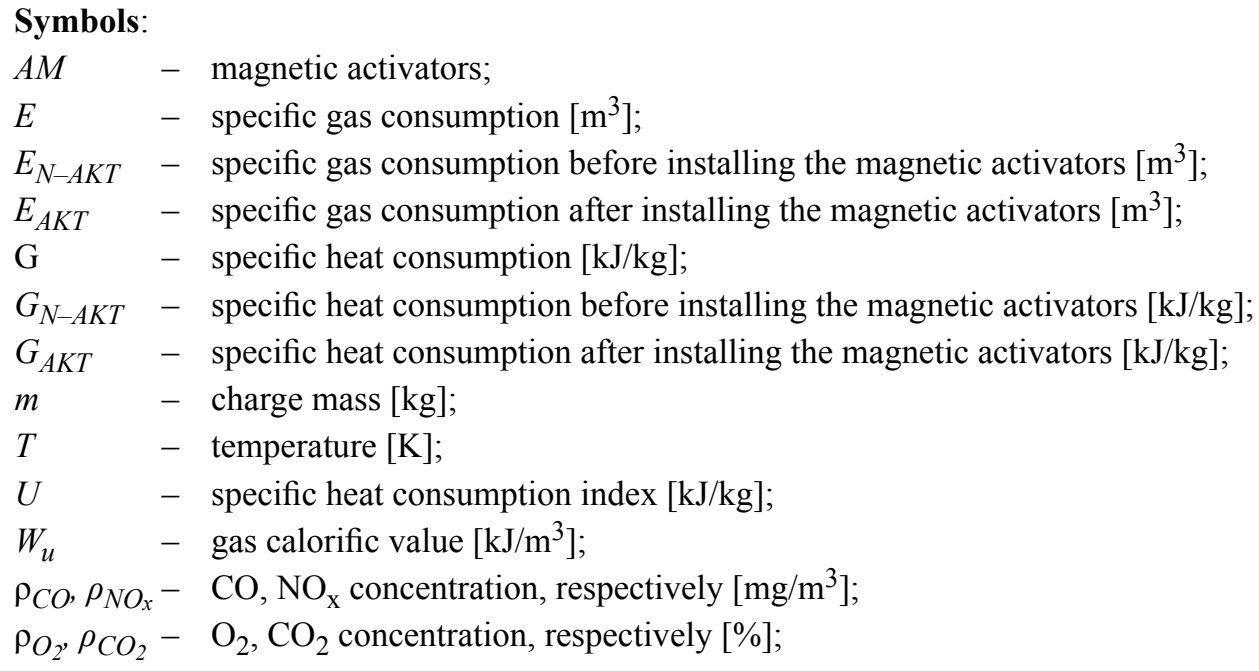

\section{References}

FEDORCHAK, V. and FEDORCHAK, T. 2015. Analysis and classification of physical and chemical methods of fuel activation. Ovidius University Annals of Chemistry vol. 26, 2, pp. 67-73.

KulaKov et al. 2017 - Kulakov, A.V., Rantsev-Kartinov V.A. and TyUtyUnNiK, V.M. 2017. Application of universal multipurpose modules of industrial disintegrators/activators for the processing of cereals and potatoes into starch products. International Jurnal of Advanced Research vol. 5, 5, pp. $1759-1762$.

KUlAKOV et al. 2018 - KUlAKOV, A.V., RANTSEV-KARTINOV, V.A. and TYUTYUNNIK, V.M. 2018. New technologies for processing coal using universal module industrial disintegrators/activators. American Journal of Engineering Research vol.7, 11, pp. 33-41.

MichalaK, W. 1994. Unipolar magnetizers in Krotoszyn PCB (Magnetyzery jednobiegunowe w Krotoszyńskim PCB). Materiały Budowlane vol. 2, pp. 32-38 (in Polish).

MozGA, $Ł$. and STOECK, T. 2018. The influence of magnetic activators on the fuel consumption of a spark -ignition engine (Wpływ aktywatorów magnetycznych na zużycie paliwa silnika o zapłonie iskrowym). Eksploatacja i testy 9/2018 Autobusy, pp. 159-161 (in Polish).

PAJDAK, A. and WALAWSKA, B. 2016. The use of modified sodium sorbents to remove $\mathrm{SO}_{2}$ and $\mathrm{HCl}$ from power plants and CHP plants in the light of the energy policy of the European Union. Polityka Energetyczna - Energy Policy Journal vol. 19, 2, pp. 135-148.

Patent PL 186233, 2003. Urządzenie do aktywacji mediów stałych, ciekłych i gazowych zwłaszcza pyłu węglowego i innych paliw węglowodorowych.

Patent PL 214633, 2013. Device for the magnetic activation of liquid and gaseous dust media (Urzadzenie do magnetycznej aktywacji mediów pyłowych cieklych i gazowych) (in Polish).

Patent US 3228868A, 1958. Process for the conversion of hydrogen.

Patent US6143045 A, 2000. Method and a device for the magnetic activation of solid, liquid and gas media, especially coal dust and other hydrocarbon fuels.

SŁAWIŃSKI et al. 2014a - SŁAWIŃSKI, K., GANDOR, M., KNAŚ, K., BALT, B. and NowAK, W. 2014a. Electromagnetic mill and its application for drying coals (Mtyn elektromagnetyczny i jego zastosowanie do suszenia wegli). Rynek Energii vol. 1, pp. 140-150 (in Polish). 
SŁAWIŃSKI et al. 2014b - SŁAWIŃSKI, K., KNAŚ, K., GANDOR, M. and NOWAK, W. 2014b. Valorisation of industrial waste in an electromagnetic activator - alternative fuels of the future (Waloryzacja odpadów przemystowych $w$ aktywatorze elektromagnetycznym - alternatywne paliwa przyszłości). Prace Instytutu Ceramiki i Materiałów Budowlanych vol. 19, pp. 93-101 (in Polish).

SZCZYPIOROWSKI, A. 1994. The use of a magnetic field to improve combustion processes (Wykorzystanie pola magnetycznego do poprawy procesów spalania). Gospodarka Paliwami i Energia vol. 10, pp. 12-17 (in Polish)

SzCZYPIOROWSKI, A. 1993. Magnetizer - a modern ecological tool (Magnetyzer nowoczesne narzędzie ekologiczne). Gaz, Woda i Technika Sanitarna vol. 3, pp. 26-32 (in Polish).

SZCZYPIOROWSKI, A. and NOWAK, W. 1995. Analysis of the possibilities of using a magnetohydrodynamic method of activating fuels in internal combustion drives (Analiza możliwości wykorzystania magnetohydrodynamicznej metody uaktywniania paliw w napędach spalinowych). Gospodarka Paliwami i Energia vol. 3, 1, pp. 2-6 (in Polish).

Walawska et al. 2014 - Walawska, B., SzymaneK, A., PAJDAK, A. and NowaK, M. 2014. Flue gas desulfurization by mechanically and thermally activated sodium bicarbonate. Polish Journal of Chemical Technology vol. 16, 3, pp. 56-62.

WITASZAK, K. 1995. The cheapest technology to reduce gas and oil consumption (Najtańsza technologia zmniejszania zużycia gazu i oleju). Ceramika Budowlana vol. 10, pp. 7-10 (in Polish).

\section{Oddziaływanie zastosowania magnetycznych aktywatorów paliwa na proces spalania w hutniczych piecach grzewczych}

\section{Streszczenie}

W artykule przedstawiono wyniki testów zastosowania magnetycznych aktywatorów paliw, poprawiających efektywność pracy hutniczych pieców grzewczych oraz wpływających pozytywnie na aspekty ekologiczne ich pracy. Zamieszczono wskaźniki energetyczne pracy pieców hutniczych w czasie eksploatacji, przed i po zainstalowaniu magnetycznych aktywatorów paliw oraz wyniki składu i stężenia emitowanych zanieczyszczeń.

Magnetyczna aktywacja paliw płynnych i gazowych modyfikuje ich strukturę. W wyniku aktywacji w strefie swobodnego przepływu paliwa dochodzi do selektywnego nasycenia mieszanki paliwowej tlenem. Dochodzi do zbliżenia warunków spalania do optymalnych, czego dowodem jest redukcja zanieczyszczeń w spalinach. Wymiernym efektem ekonomicznym jest również oszczędność paliwa w procesie spalania.

W ramach niniejszej pracy przeprowadzono badania na piecach wybranych typów: przepychowym, wgłębnym jedno- i dwukomorowym oraz piecu z trzonem obrotowym. Przeprowadzono kilkunastomiesięczne cykle pomiarowe na każdym z obiektów. Badania polegały na analizach jednostkowego zużycia gazu oraz ciepła w poszczególnych obiektach badawczych przed oraz po zastosowaniu magnetycznych aktywatorów paliwa. W oparciu o rezultaty przeprowadzonych testów stwierdzono skuteczność stosowa- 
nia aktywatorów. W wyniku dwunastomiesięcznego cyklu badań na piecu typu przepychowego uzyskano $36 \%$ zmniejszenie jednostkowego zużycia gazu oraz $22 \%$ zmniejszenie jednostkowego zużycia ciepła. Po siedemnastomiesięcznym cyklu pomiarowym na piecach typu wgłębnego otrzymano spadek zużycia gazu o $35 \%$ oraz zużycia ciepła o $6 \%$. Badania na piecach z trzonem obrotowym trwały czternaście miesięcy i wykazały zmniejszenie poziomu zużycia gazu o 8\%. We wszystkich obiektach z zainstalowanymi aktywatorami magnetycznymi uzyskano również poprawę składu spalin w atmosferze piecowej i obniżenie emisji szkodliwych zanieczyszczeń do atmosfery z instalacji.

SŁOWA KLUCZOWE: aktywacja magnetyczna, młyn magnetyczny, hutnicze piece grzewcze, paliwo, spalanie 